\title{
MENYELISIK BUdAYA pASAR TRADISIONAL DI pasar Baru BaLIKPAPAN, KOTA BALIKPAPAN, KALIMANTAN TIMUR
}

\section{THE REVEAL OF MARKET CULTURE IN THE TRADITIONAL MARKET OF PASAR BARU IN BALIKPAPAN CITY, EAST KALIMANTAN}

\author{
Budiawati Supangkat $^{1}$, Rahman Latif Alfian ${ }^{2}$, Johan Iskandar ${ }^{3}$ \\ ${ }^{1}$ Departemen Antropologi, FISIP, Unpad, dan Pusat Riset Gender dan Anak Unpad, \\ Kampus Jatinangor, Jl. Raya Bandung-Sumedang KM21, Sumedang 45363. \\ ${ }^{2}$ Fakultas Ushuluddin, Adab dan Humaniora, IAIN Purwokerto. \\ Jl. A. Yani No. 40A, Purwokerto, 53126. \\ ${ }^{3}$ Departemen Biologi Fmipa, dan Pasca Ilmu Lingkungan (PSMIL \&DIL) Unpad, \\ Kampus Jatinangor, Jl. Raya Bandung-Sumedang Km 21, Jatinangor, Sumedang 45363 \\ 1,2,3 e-mail: budiawati.supangkat@unpad.ac.id, rahmanlatif927@gmail.com, \\ johan.iskandar@unpad.ac.id
}

DOI: $10.30959 /$ patanjala.v13i2.795

\begin{abstract}
Abstrak
Artikel ini membahas mengenai budaya pasar yang berlangsung di Pasar Baru Kota Balikpapan. Budaya pasar sendiri merupakan keseluruhan norma dan nilai yang melingkupi kegiatan pemangku pasar tradisional dalam berkegiatan di pasar. Penelitian ini menggunakan metode etnografi dalam menggali data dari para pemangku Pasar Baru yang menjadi lokus penelitian. Etnografi dipilih karena penelitian ini berusaha menjaring data baik itu data lisan, visual maupun tertulis dari sudut pandang pengampu Pasar Baru Balikpapan. Hasil penelitian ini menunjukkan bahwa para pedagang yang berdagang di Pasar Baru Balikpapan berasal dari latar budaya yang beragam. Mengingat Balikpapan merupakan salah satu wilayah strategis juga pintu masuk dan jalur perniagaan khususnya di Kalimantan Timur. Dalam melakukan aktivitas perdagangan, pedagang membawa nilai budaya masing-masing. Meskipun demikian secara perlahan tercipta pola tindakan dari para pedagang. Meskipun berasal dari latar budaya yang berbeda, secara tidak tertulis para pedagang seperti telah mencapai kesepakatan dalam berkegiatan di pasar.
\end{abstract}

Kata kunci: budaya pasar, praktik, pedagang, pasar tradisional, Balikpapan.

\section{Abstract}

This article discusses the market culture at Pasar Baru in Balikpapan City. The market culture in this study can be defined as the overall norms and values adopted by traditional market stakeholders in their daily activities in the market. This study uses ethnographic methods to collect data from the stakeholders of Pasar Baru as the research locus. Ethnography was chosen based on the consideration that this research seeks to collect data, both oral, visual and written data from the point of view of the Pasar Baru supervisor in Balikpapan. The results show that the traders who trade at Pasar Baru in Balikpapan originate from the diverse cultural backgrounds. It is a consequence of the City of Balikpapan as one of the strategic areas as well as the entrance and route of commerce, especially in East Kalimantan. In their trading activities, the traders bring their respective cultural values. It slowly encourages the creation of new patterns in the behavior of traders. They seem to have reached an agreement in their activities in the market.

Keywords: market culture, practice, traders, traditional market, Balikpapan. 


\section{A. PENDAHULUAN}

"Memasuki gapura bertuliskan Pasar Baru Balikpapan, terlihat di sepanjang jalan pedagang-pedagang menggelar lapak dengan alas terpal dan tatanan sayur-mayur menawarkan dagangannya ke pengunjung yang melintas di depannya." Kondisi tersebut adalah penggalan gambaran kondisi di Pasar Baru Balikpapan pada pagi hari, situasi yang serupa juga berlangsung di pasar-pasar lainnya di Indonesia (Supangkat, 2012). Pasar Baru Balikpapan terletak di Kelurahan Kelandasan Ilir, Kota Balikpapan, Kalimantan Timur. Lokasi pasar ini berada di tengah kota, dihimpit pembangunan hotel dan pusat perbelanjaan di Kota Balikpapan. Apabila merujuk pada letak geografisnya, Pasar Baru Balikpapan bisa disebut sebagai Pasar Tradisional Kota. Namun demikan, meskipun suatu pasar terletak di dalam kota sejatinya pasar tradisional tetap memiliki karakter sosial lokal, karakter tersebut yang sering disebut sebagai budaya pasar tradisional (Effendi, 1997).

Kajian pasar terutama pasar tradisional selalu menarik perhatian dari sudut pandang sosial budaya (Direktorat Internalisasi Nilai dan Diplomasi Budaya, 2013; Hermawan, Kristiani, \& Ismiyati, 2018). Perbincangan pasar tradisional tentu mengungkap tentang ekonomi. Ekonomi sendiri terdiri atas dua ranah yaitu komunitas dan pasar. Kedua aspek tersebut membentuk ekonomi karena manusia dimotivasi oleh pemenuhan sosial, persaingan, dan tujuan akumulasi keuntungan (Gudeman, 2001). Pada dasarnya perdagangan, uang, dan pasar merupakan satu kesatuan yang tak terpisahkan. Perdagangan sendiri bukanlah aktivitas individual melainkan aktivitas kelompok, kegiatan tersebut berpusat pada pertemuan komunitas yang berbeda dengan tujuan melakukan pertukaran barang (Polanyi, 1985; Supangkat, 2012). Pasar tradisional dalam perkembangannya bukan hanya lokus bertemunya penjual dan pembeli, tetapi pasar juga menjadi tempat berlangsungnya hubungan personal maupun kelompok yang intim. Dengan kata lain pasar tradisional tidak sekadar ruang ekonomi tetapi juga ruang sosial bagi para pemangkunya (Sadilah, Arianti, Herawati, Moertjipto, \& Sukari, 2011; Seligmann, 2018). Hubungan yang terjalin antaraktor-aktor yang menghidupi pasar tradisional tidak hanya berorientasi pada perhitungan ekonomi, hubungan pribadi yang intim membuat hubungan yang terjalin tidak lagi terbebani oleh perhitungan untung rugi, tapi lebih ke pertukaran sosial (Granovetter, 2017).

Mengacu pada penjelasan sebelumnya, dapat dipahami pasar tradisional memiliki nilai dan norma yang tidak hanya berorientasi pada untung rugi yang dihidupi oleh pemangkunya. Pada penelitian sebelumnya, mengenai Orang Kalang, Cina, dan Budaya Pasar di Pedesaan Jawa (Mulyanto, 2008), budaya pasar dalam penelitian tersebut dapat dipahami sebagai cara hidup kolektif serta kumpulan nilai dan norma tersendiri yang mendorong atau membatasi pengampunya dalam perniagaan serta menjadikan pasar (market place) sebagai bagian dari kerangka psiko-geografi tradisional mereka. Dalam penelitian yang berjudul Studi Budaya Pasar Tradisional dan Perubahan Gaya Hidup Masyarakat Pedesaan, Effendi (2016) mengartikan budaya pasar terwujud dalam empat bentuk yaitu artifacts (benda-benda materiil), sistem tingkah laku dan tindakan yang berpola, sistem gagasan, dan seperangkat nilai.

Melalui pemahaman mengenai batasan budaya pasar seperti yang dipaparkan pada penelitian sebelumnya, penelitian ini berusaha menyelisik lebih dalam budaya pasar tradisional yang teraktual pada masyarakat perkotaan. Dalam penelitian ini pasar yang dimaksud adalah Pasar Baru Kota Balikpapan yang merupakan salah satu pasar tradisional di tengah Kota Balikpapan, Kalimantan Timur. Fokus kajian pada penelitian ini seperti yang dijelaskan oleh Damsar, 
bahwa kajian sosiologi pasar dapat dipahami sebagai sebuah kajian yang mempelajari hubungan antara masyarakat dan pasar yang dalam hubungan tersebut dapat dilihat bagaimana masyarakat memengaruhi pasar serta sebaliknya bagaimana pasar memengaruhi masyarakat (Damsar \& Indrayani, 2018). Hal ini menjadi penting mengingat pasar tradisional menjadi tempat berpindahnya suatu komoditas dari satu orang ke orang lain, dari satu daerah ke daerah lain, dan satu peranan ke peranan lainnya, sehingga dalam "kehidupannya" para pedagang pasar tradisional sangat mengandalkan pola komunikasi dan relasi yang dibangun dalam waktu yang tidak sebentar (Belshaw, 1965).

Pada sisi yang lain, penelitian ini menjadi penting karena pada kenyataannya budaya pasar bukan sesuatu yang "bulat" yang di dalamnya homogen. Penelitian dalam psikologi budaya dan antropologi psikokultural menjelaskan bahwa subjektivitas manusia tidak hanya ditentukan oleh sebuah budaya tunggal melainkan ditentukan oleh interaksi simbolisme budaya, biografi individu, kebiasaan-kebiasaan yang menyatu dalam kehidupan harian dan pikiran yang penuh pertimbangan (Hefner, 2000). Dengan kata lain, budaya bukanlah suatu kenyataan sosial yang selesai, yang terinternalisasi oleh subjek-subjek budaya yang pasif karena para pedagang pasar tradisional merupakan aktor-aktor aktif yang selalu "bergerak".

Memahami budaya pasar juga menjadi penting karena pada dasarnya pemahaman mengenai pola hidup para pedagang dan pengalaman perdagangan membentuk gagasan individu tentang diri dan kepribadian, tidak hanya sebagai pelaku ekonomi tetapi dalam hal lain seperti pemahaman mengenai gender, kelas, etnis, hingga bagaimana bentuk kepribadian para pedagang membentuk aspek-aspek budaya suatu pasar atau pasar tradisional (Endres \& Leshkowich, 2018).

\section{B. METODE PENELITIAN}

Artikel ini melihat lebih dalam bagaimana budaya pasar yang terbangun dan berjalan di pasar tradisional, khususnya Pasar Baru Kota Balikpapan, Kalimantan Timur. Budaya pasar yang tertuang dalam praktik pengampu pasar sehari-hari kemudian digali menggunakan metode etnografi. Penggunaan etnografi sebagai metode penelitian dipilih karena etnografi dapat menceritakan atau juga menggambarkan kisah yang berakar dari sudut pandang masyarakat lokal saat mereka menjalani kehidupan sehari-hari di komunitasnya (Fatterman, 2010). Selain itu, penggunaan etnografi juga merupakan upaya untuk memperhatikan makna tindakan dari kejadian yang ada pada kelompok masyarakat yang diamati (Spradley, 2007).

Metode etnografi mengadopsi lensa budaya untuk menafsirkan perilaku yang diamati, memastikan bahwa perilaku ditempatkan dalam konteks yang relevan dan bermakna secara budaya (Fatterman, 2010). Dalam penelitian ini pembacaan konsep kebudayaan dipahami sebagai suatu dimensi yang aktif dan konstitutif dari kehidupan sosial daripada sekadar mekanisme penjamin integrasi sosial, budaya menjadi blueprint seseorang maupun masyarakat menciptakan dunia mereka yang bermakna dalam dua level sekaligus: emosi dan kognitif (Geertz, 1973). Kebudayaan yang dibentuk kemudian dilihat sebagai budaya diferensial yang tumbuh dari adanya interaksi yang terus menerus antarmanusia, kelompok, dan lingkungan yang terus menerus mengalami perubahan (Abdullah, 2015).

Dalam penelitian ini pasar tradisional dilihat dalam empat wujud yaitu, (1) eksistensi fisik tempat (bangunan pasar) seperti lahan, tipe bangunan, dan lain-lain; (2) Seperangkat aktivitas (baik ekonomi maupun sosial) yang berlangsung terus menerus saat kegiatan pasar berlangsung; (3) Sistem gagasan yang melatarbelakangi berlangsungnya eksistensi fisik dan seperangkat aktivitas; 
(4) Nilai yang menjadi dasar bagi sistem penyelenggaraan budaya di pasar tradisional (Effendi, 2016).

Pengumpulan data dalam penelitian ini dilakukan menggunakan beberapa teknik seperti observasi dan wawancara. Untuk metode observasi, peneliti melakukan pengamatan dengan ikut berbaur dengan kegiatan yang terjadi di Pasar Baru Balikpapan. Teknik pengumpulan data ini dilakukan karena untuk memahami masyarakat yang liyan, antropolog membenamkan dirinya di dalam komunitas yang diteliti, di dalamnya peneliti belajar, berpikir, melihat, merasakan, dan terkadang bertindak sebagai anggota pemangku kebudayaan, dan pada sisi yang lain peneliti mencatat apa saja yang dilihat dan dirasakannya (Powdermaker, 1966). Selain itu pengamatan juga dilakukan secara rinci, hal ini diperlukan karena pengamatan rinci tersebut memungkinkan kita untuk mempelajari banyak aspek yang berbeda, memeriksa dalam hubungannya satu dengan yang lain, melihat proses dalam lingkungan utuh, dan juga memanfaatkan kapasitas peneliti untuk verstehen atau memahami lebih dalam sehingga menjaring pandangan yang holistik (Valdelin, 2000). Dalam melakukan observasi terdapat beberapa hal yang diamati seperti kegiatan yang dilakukan oleh pedagang di pasar tradisional, pola komunikasi dan interaksi yang dilakukan oleh para pedagang, dan tindakan-tindakan yang dilakukan dalam menghadapi kondisi pandemi seperti saat ini.

Selain melakukan pengamatan, pengumpulan data juga dilakukan dengan wawancara kepada pedagang dan aktoraktor di Pasar Baru Balikpapan. Wawancara yang dilakukan antara lain wawancara mendalam, wawancara ini ditujukan untuk menjaring data dari pedagang yang berkaitan dengan kondisi pasar dari waktu ke waktu (historis), lalu untuk melihat penjelasan mendalam ketika menghadapi situasi pandemi seperti sekarang ini. Wawancara mendalam ditujukan kepada informan yang dirasa mengetahui secara mendalam data yang diperlukan seperti pedagang yang sudah berjualan lama, pengelola pasar, maupun beberapa aktor yang berada di pasar. Meskipun dalam konsepnya terdapat wawancara terstruktur, pada kenyataannya informan dan responden bukanlah subjek pasif yang menunggu untuk mengungkapkan informasi dan wawasan mereka, tetapi informan juga merupakan penafsir situasi yang aktif dan memiliki perhatian mereka sendiri yang mungkin tidak terlihat oleh peneliti (Soulsby, 2004). Selain wawancara mendalam, peneliti juga menggunakan model wawancara tak berencana dan wawancara sambil lalu (Koentjaraningrat, 1991). Kedua model wawancara ini dutujukan kepada pengunjung pasar maupun masyarakat umum yang dilakukan secara acak. Wawancara ini bertujuan untuk melengkapi dan pengecekan data penelitian yang diperoleh dari hasil wawancara mendalam. Model wawancara ini sering digunakan peneliti ketika berada di warung makan, ketika bertemu dengan pengunjung pasar secara acak dan tanpa direncanakan. Model wawancara ini sering digunakan peneliti ketika mengamati kondisi pasar, maupun saat melakukan pengamatan dengan berkeliling Pasar Baru Balikpapan.

Salah satu yang menjadi tantangan tersendiri bagi peneliti dalam mencari data adalah proses membangun raport atau hubungan dengan para informan. Pasar Baru dan para pedagang di Pasar Baru telah mengalami lika-liku yang panjang hingga sampai pada posisi sekarang. Hal ini menimbulkan kecurigaan tersendiri kepada peneliti ketika melakukan penelitian. Tidak jarang pedagang menyangka peneliti adalah pengelola pasar yang akan mengubah bangunan pasar "lagi". Kondisi yang demikian membuat peneliti membutuhkan waktu lebih dalam membangun kepercayaan dari para pedagang. Pada lain sisi, berbagai kepentingan yang melingkupi "kehidupan" 
pasar juga menjadi tantangan tersendiri bagi peneliti. Meskipun demikian penggunaan triangulasi sebagai cara memvalidasi data sangat berguna sehingga peneliti banyak membandingkan data dari satu informan dengan informan lainnya.

Analisis data penelitian menggunakan analisis data kualitatif (Miles \& Huberman, 1992). Analisis data tersebut terdiri dari empat alur kegiatan yaitu pengumpulan data, reduksi data, penyajian data, dan penarikan kesimpulan atau verifikasi. Proses tersebut dilakukan secara berulang-ulang hingga mendapatkan suatu pola tertentu pada masyarakat yang diteliti. Dalam melakukan analisis data alur tersebut tidak selalu berurutan karena langkah-langkah tersebut merupakan sesuatu yang jalin-menjalin pada saat sebelum, selama, dan sesudah pengumpulan data dalam bentuk yang sejajar, untuk membangun wawasan umum yang disebut analisis. Adapun dalam proses verifikasi data, peneliti menggunakan triangulasi. Peneliti membandingkan data hasil observasi dengan data yang didapat pada saat wawancara. Peneliti juga membandingkan data wawancara dari satu informan ke informan yang lainnya.

Pasar Baru Balikpapan berada di Kelurahan Klandasan Ilir. Pada gambar 1 dapat dilihat lokasi Pasar Baru Balikpapan berada tepat di pinggir Selat Makassar. Jarak dengan pusat Kecamatan Balikpapan Kota $\pm 3 \mathrm{Km}$. Pasar Baru bukan satusatunya pasar di Kecamatan Balikpapan Kota. Tidak jauh dari lokasi Pasar Baru Balikpapan terdapat Pasar Klandasan yang berada di Kelurahan Klandasan Ulu dan hanya berjarak $\pm 1 \mathrm{Km}$ dari Pasar Baru Balikpapan. Kedua pasar tersebut merupakan pasar tradisional tetapi di bawah pengelola yang berbeda. Pasar Baru Balikpapan dikelola oleh pihak swasta yaitu PT. Hasta Kreasi Mandiri yang dalam pengelolaannya selalu berkoordinasi dengan pihak Pemerintah Kota Balikpapan. Sedangkan, Pasar Klandasan dikelola oleh Pemerintah Kota Balikpapan di bawah Dinas Perdagangan Kota Balikpapan.
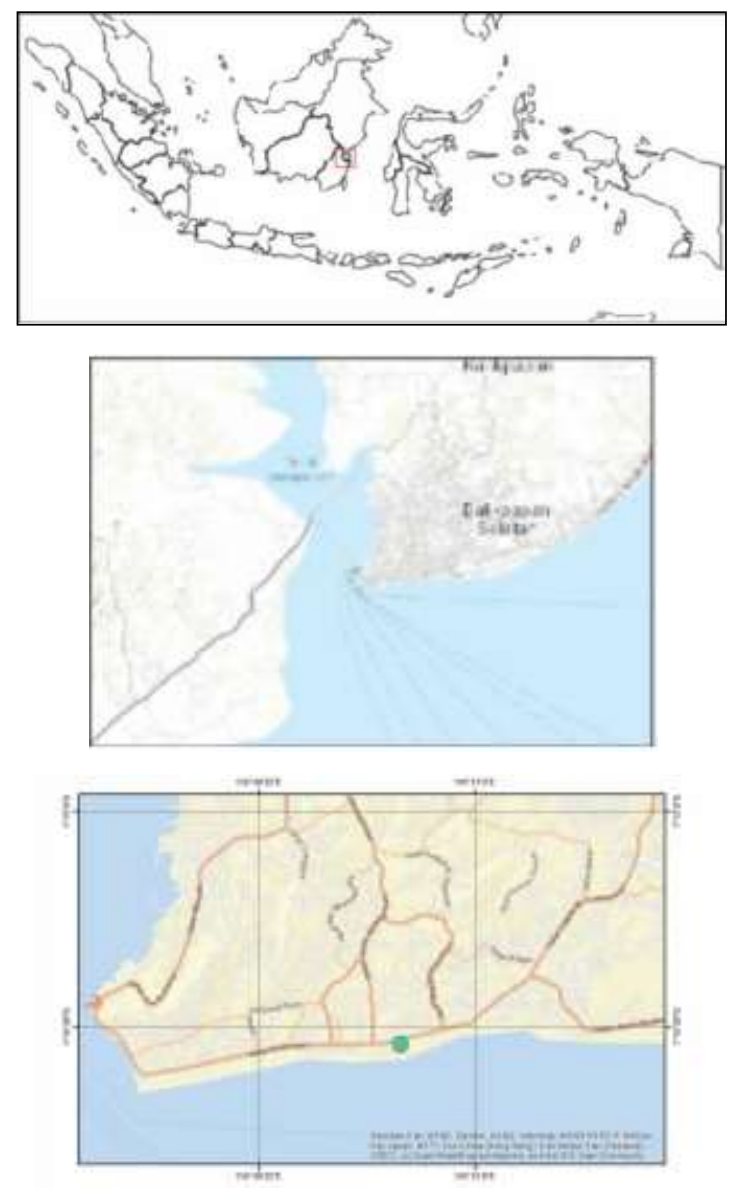

Gambar 1. Peta Lokasi Pasar Baru Balikapapan

Sumber: Dokumentasi Peneliti, 2018.

Pasar Baru Balikpapan dipilih sebagai lokus karena lokasinya strategis secara sosial. Pasar ini tidak jauh dari pusat pemerintahan Kota Balikpapan, hanya berjarak 1,8 $\mathrm{Km}$ dari kantor Walikota Balikpapan. Pasar Baru juga tidak jauh dari Bandara Sultan Aji Muhammad Sulaiman Sepinggan, yaitu hanya butuh 20 menit bila ditempuh berkendara. Selain tidak jauh dari bandara, letak Pasar Baru Balikpapan juga tidak jauh dari Pelabuhan Semayang yang merupakan pelabuhan di Kota Balikpapan, yaitu hanya berjarak 4,8 $\mathrm{Km}$ atau hanya butuh 15 menit bila ditempuh dengan berkendara. Lokasi yang 
strategis ini membuat Pasar Baru Balikpapan menjadi salah satu tujuan bagi warga sekitar maupun pendatang untuk mengadu nasib dan mencukupi kebutuhan sehari-hari.

Hal tersebut tercermin dengan beragamnya asal pedagang yang berdagang di Pasar Baru Balikpapan seperti dari Penajam, Sulawesi Selatan seperti Makassar, Banjarmasin, Jawa, Madura, maupun Sumatra seperti orang Minang. Banyaknya pendatang yang berdagang di Pasar Baru membawa juga pengetahuan yang mereka miliki dari pengalaman dan budaya masing-masing. Hal inilah yang menjadi fondasi dalam melihat pengetahuan para pedagang terutama pedagang ikan dalam penyebutan dan pengetahuan pada ikan yang diperjualkan. Lokasi Pasar Baru Kota Balikpapan dapat dilihat pada gambar 1 .

\section{HASIL DAN BAHASAN \\ 1. Gambaran Rupa Fisik Pasar Baru Balikpapan}

Nama Pasar Baru bagi warga masyarakat tergolong baru, sebelumnya Pasar Baru lebih dikenal dengan Pasar Balcony. Penyebutan Balcony sendiri merujuk pada nama pusat perbelanjaan yang berada di Kota Balikpapan yaitu Balcony City sebelum berubah nama menjadi Balikpapan Ocean Squere. Pasar Baru sendiri terletak di area basement pusat perbelanjaan tersebut. Hal tersebut yang membuat banyak masyarakat mengenalnya dengan nama Pasar Balcony.

Hingga sekarang belum diketahui secara pasti bagaimana sejarah pasar ini dibangun. Belum ditemukan secara riil dokumen yang membahas sejarah Pasar Baru pada masa lampau. Tetapi dari beberapa cerita yang dihimpun dari pedagang pasar, pasar tersebut diyakini sudah ada pada tahun 1970-an. Salah satu informan sebut saja Mbah Karti $( \pm 75$ tahun) menceritakan bahwa beliau adalah perantau dari Jawa tepatnya dari Surabaya. Awal mula beliau sampai di Balikpapan beliau menggambarkan: "Pada waktu pertama sampai wilayah di sini masih sepi, jalanannya masih kecil dan banyak hutanhutan. Dulu pasar ini juga pasar kecil tempatnya ada di depan sana dekat jalan raya yang sekarang." (Wawancara, 27 Agustus 2019). Beberapa pedagang juga menjelaskan bahwa penamaan Pasar Baru tersebut karena pasar tersebut dibangun kembali seperti baru lagi. Para pedagang menceritakan bahwa Pasar Baru pernah terbakar beberapa kali. Pada awalnya Pasar Baru terletak lebih ke depan dari lokasi yang sekarang, lebih tepatnya di pinggir jalan raya. Pasar ini tidak dibangun secara formal oleh pemerintah tapi lebih ke perkumpulan pendatang yang membuka lapak-lapak dari kayu untuk berdagang.

Pedagang menceritakan bahwa tidak banyak kios yang dibangun permanen, kebanyakan kios dan lapak terbuat dari kayu. Mereka pun menggambarkan bahwa kondisi Pasar Baru pada saat itu adalah pasar yang kurang tertata dan penuh kesederhanaan. Hal ini yang membuat Pasar Baru beberapa kali mengalami kebakaran karena material yang dipakai untuk mendirikan kios atau lapak terbuat dari kayu sehingga mudah terbakar. Seorang pedagang sebut saja Bu Haji (55 tahun, bukan nama sebenarnya) menceritakan:

"Pasar Baru pernah terbakar empat kali, yaitu tahun 1986, tahun 1990, tahun 1994, dan yang terakhir itu kalau tidak tahun 2006 ya 2007. Saya kena imbasnya semua itu. Ada beberapa kejadian yang menjadi penyebab kebakaran pada waktu itu. Pada saat kebakaran pertama kata orang penyebabnya itu lilin dari salah satu pedagang. Ada juga pada tahun 2000-an itu karena korsleting listrik. Tapi ya enggak ada yang tahu pasti penyebab kebakaran itu." (Wawancara, 26 Agustus 2018).

Oleh karena keterbatasan dokumen tertulis maupun foto-foto masa lalu Pasar Baru, kisah-kisah yang melingkupinya pun beragam. Meskipun demikian dari cerita 
para pedagang tersebut, peneliti berkesempatan melihat bagaimana para pedagang memaknai Pasar Baru sebagai lokus yang mereka hidupi dan tempat mereka hidup.

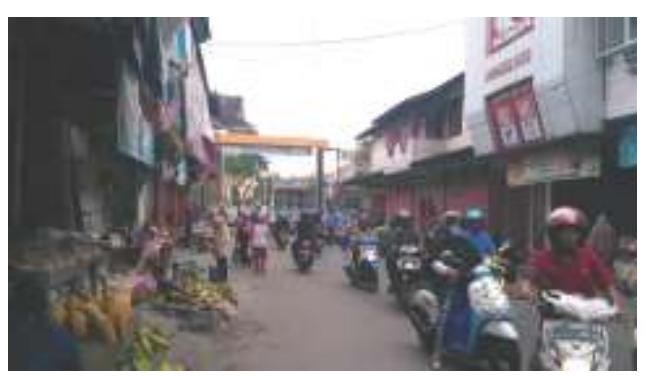

Gambar 2. Suasana di Sepanjang Jalan Setelah Gapura Masuk Pasar Baru Balikpapan Sumber: Dokumentasi Peneliti, 2018.

Lokasi Pasar Baru Balikpapan sekarang berada di area basement pusat perbelanjaan Balikpapan Ocean Squere. Tidak sulit untuk menemukan pasar tradisional ini karena terdapat gapura bertuliskan Pasar Baru Balikpapan yang berada di pinggir Jalan Jenderal Sudirman, jalan utama Kota Balikpapan. Bentuk bangunan Balikpapan Ocean Squere yang berbentuk seperti ombak air laut juga menjadi penanda tersendiri untuk mempermudah pengunjung dalam mengunjungi Pasar Baru Balikpapan. Pada pagi hari, keramaian Pasar Baru terlihat dari jalan raya yang melintasi di depan gerbang. Antrean angkutan kota menunggu penumpang juga sering terlihat tidak jauh dari gapura masuk, yang tentu saja menambah suasana ramai dan sibuk kegiatan pasar pada pagi hari. Memasuki gapura bertuliskan Pasar Baru Balikpapan, pengunjung akan melihat beberapa pedagang menggelar alas-alas untuk berjualan sembari menawari siapa saja yang melintas. Selain pedagang yang berjualan di trotoar tidak sedikit pula pedagang yang berjualan dari mobil bak terbuka. Beberapa pedagang juga terlihat menggunakan gerobak dorong roda satu (umumnya untuk mengangkut pasir/tanah) yang difungsikan sebagai lapak atau media menata dagangannya. Jalan masuk menuju bangunan pasar menjadi jalan yang sibuk pada pagi hari terutama ketika hari libur seperti yang tampak pada Gambar 2 .

Untuk masuk ke dalam pasar, terdapat beberapa pintu yang bisa menjadi akses bagi para pengunjung pasar. Pintu tersebut berada di sisi Barat, Utara, dan Timur. Banyaknya pintu masuk tersebut memudahkan pengunjung untuk memasuki Pasar Baru. Letak pasar yang berada di basement membuat suasana di Pasar Baru memiliki kekhasan tersendiri. Hal yang paling terasa adalah udara yang sedikit pengap dan lampu-lampu yang menyala di siang hari. Pasar yang terletak di area basement membuat sinar matahari pada siang hari tidak masuk dengan sempurna, kondisinya cenderung gelap ketika lampulampu toko tidak dinyalakan. Kekhasan selanjutnya dari bangunan fisik Pasar Baru Balikpapan adalah banyaknya pipa-pipa dan saluran udara yang melekat pada atap pasar. Pipa-pipa dan saluran udara tersebut berfungsi menyuplai udara dan air untuk bangunan pusat perbelanjaan yang berada di atasnya. Selain itu, suara genset penyuplai listrik dan air kompresor juga menjadi hal yang menambah dan mewarnai riuhnya suara para pengampu Pasar Baru Balikpapan.

Di bagian dalam, tata letak pasar ditata sedemikian rupa oleh pengelola. Pada dasarnya pada saat awal setelah dibangun, pedagang ditata sesuai dengan jenis dagangannya. Namun demikian setelah beberapa tahun, ditambah pusat perbelanjaan (mall) belum sepenuhnya aktif tata letak pedagang sedikit banyak berubah tidak seperti perencanaan di awal. Tidak jarang ketika berkeliling mengitari pasar, ditemukan satu-dua kios yang menjual komoditas berbeda dengan kios lain. Misalnya saja ditemukan kios penjual pisang, di tengah kios peracangan dan sembako. Salah satu yang melatarbelakangi fenomena ini adalah telah berpindahnya kepemilikan kios. 


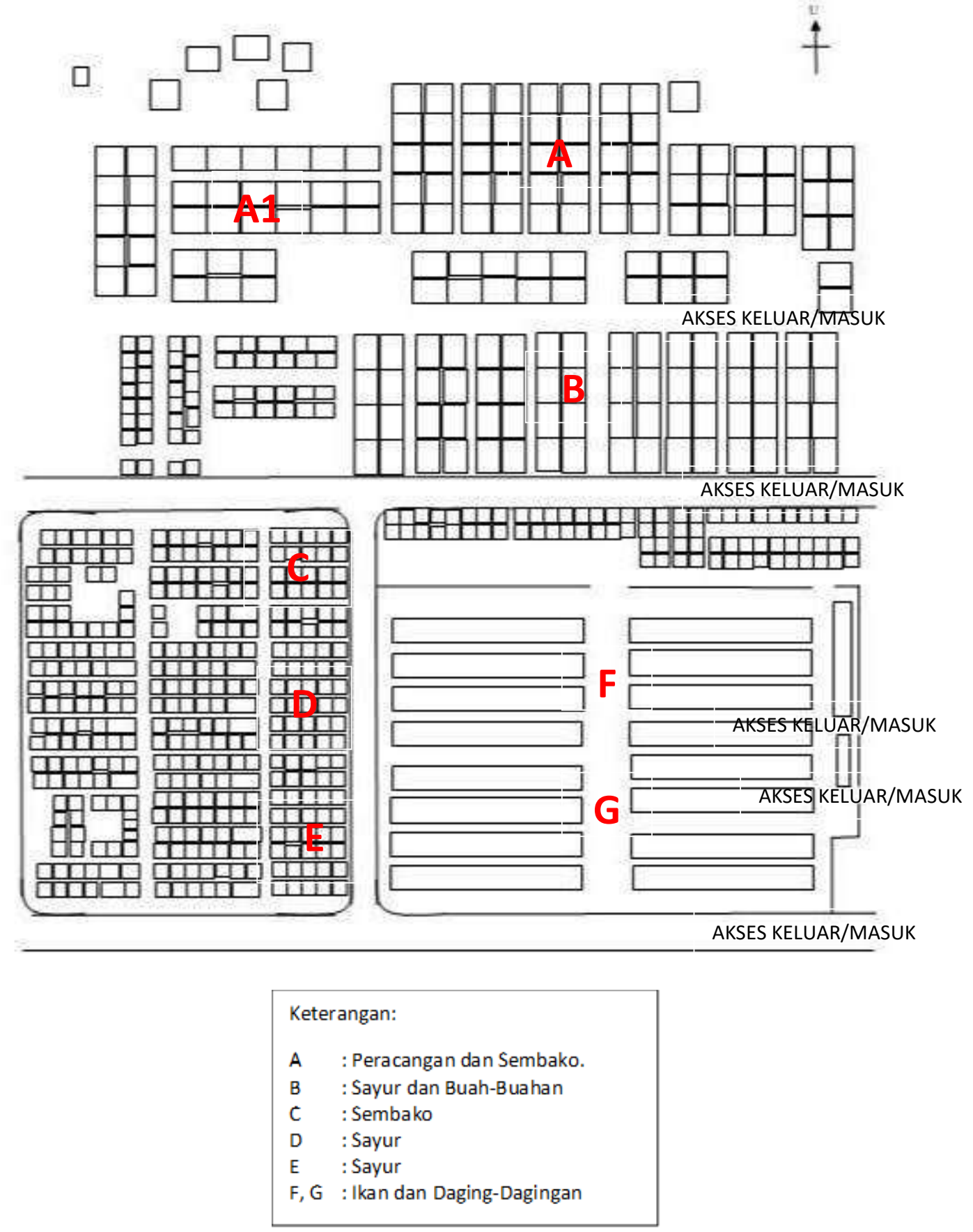

Gambar 3. Denah Pasar Baru Balikpapan

Sumber: Dokumentasi dan Olahan Peneliti, 2018 
Beberapa pedagang memutuskan untuk menjual atau mengalihkan sewa kios kepada orang lain karena lika-liku berdagang yang tidak sesuai dengan rencana pedagang. Peralihan kepemilikan ini yang membuat pemilik baru, tidak semuanya meneruskan menjual komoditas pedagang sebelumnya. Di dalam pasar juga sering ditemui pedagang yang berdagang di lapak-lapak kecil, meskipun jumlahnya tidak sebanyak yang ditemui di luar pasar. Para pedagang ini biasanya menjual sayur, atau jajanan pasar. Meskipun demikian secara keseluruhan pedagang di dalam pasar masih tertata rapi.

Pada saat penelitian ini dilakukan, tidak semua blok di dalam Pasar Baru terisi. Misalnya saja pada beberapa blok di sebelah Barat yang tidak terisi selain di blok bagian Barat. Beberapa blok yang berada di sisi Selatan juga tidak banyak yang mengisi. Hanya beberapa kios yang buka dan didapati aktivitas pedagang. Kedua blok tersebut nampak lebih gelap, meskipun pada saat aktivitas pasar sedang ramai-ramainya. Lampu-lampu tidak dinyalakan, dan banyak kios yang kurang terawat karena tidak memiliki penyewa. Para pedagang menuturkan alasan utamanya adalah karena kondisi pasar yang tidak seramai dulu dan juga keterbatasan modal dari para pedagang. Gambaran penataan kios di Pasar Baru Balikpapan dapat dilihat pada denah Pasar Baru yang tersaji dalam Gambar 3.

\section{Rupa-Rupa Pedagang di Pasar Baru Balikpapan}

Pedagang di Pasar Baru Balikpapan, sebagian besar merupakan perantau dari berbagai daerah. Seperti dari Sulawesi Selatan, Banjarmasin, Jawa, Madura, dan juga Sumatera. Setiap pedagang mempunyai komoditas perdagangan yang berbeda antara satu sama lain. Selain komoditas, media atau tempat berdagang para pedagang di Pasar Baru Balikpapan juga beragam. Berbeda dengan pedagang di Pasar Beringharjo yang menggunakan lapak, kios, los pasar, dan alas terpal sebagai media dalam menggelar dan menjajakan komoditas dagangannya (Supangkat, Alfian, \& Iskandar, 2021). Para pedagang di Pasar Baru Balikpapan menggunakan media atau tempat berdagang yang beragam seperti menggunakan mobil, gerobak dorong, motor, kios, lapak, los, toko, dan lesehan (menggelarnya di tanah). Rupa media atau tempat berdagang ini dapat dilihat pada Gambar 4.
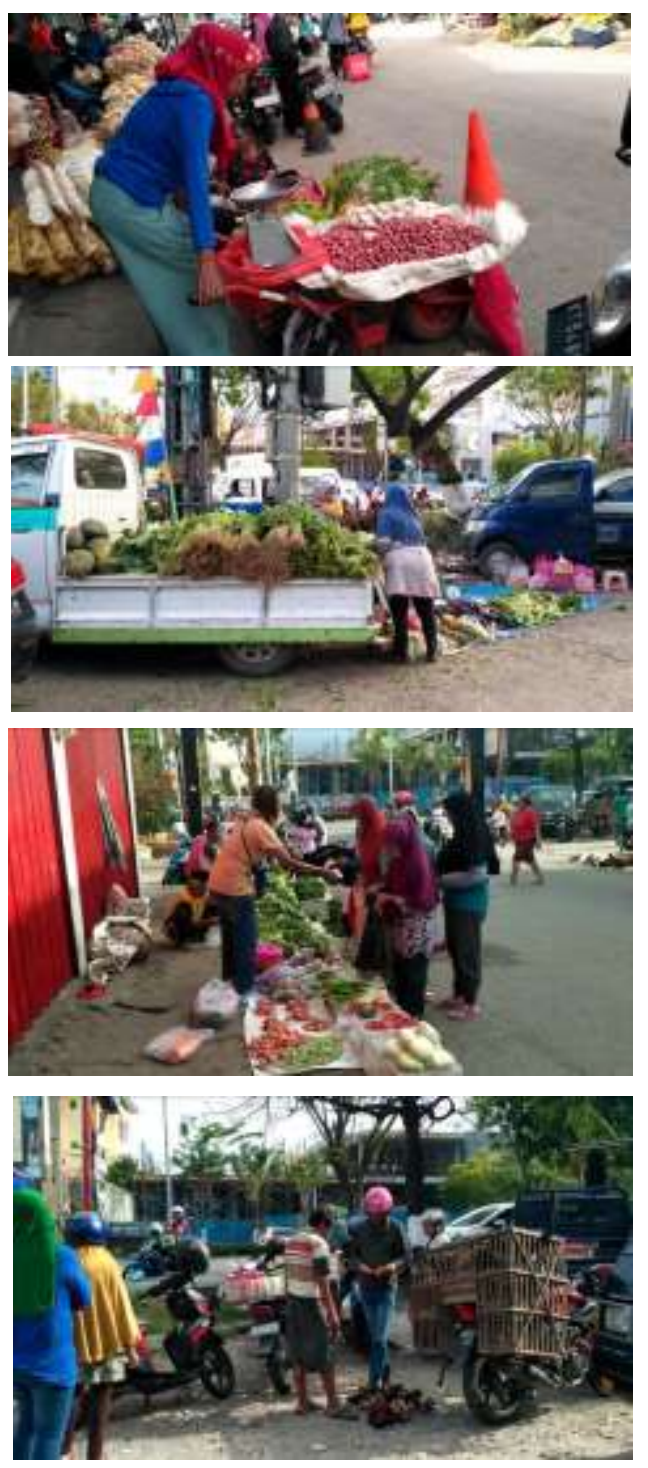

Gambar 4. Rupa Tempat dan Media Berdagang Sumber: Dokumentasi Peneliti, 2018. 
Jenis pedagang yang digambarkan pada Gambar 4 merupakan pedagang yang berdagang di luar pasar. Media atau tempat berjualan yang beragam pada pedagang di luar pasar dilandasi beberapa faktor, misalnya kepraktisan, memaksimalkan mobilitas, dan keterbatasan modal. Para pedagang yang menjajakan komoditas dagangannya di luar pasar, merupakan pedagang pagi. Pedagang pagi ini mempunyai keterbatasan waktu dalam berdagang, biasanya tidak lebih dari pukul 10.00 WITA. Para pedagang pagi ini mulai menggelar dan menata dagangannya semenjak subuh, sebelum para pedagang yang berada di dalam pasar membuka kiosnya masing-masing. Sasaran konsumen para pedagang pagi ini adalah pedagang sayur keliling (warga setempat menyebutnya Pedagang Sayur Motor) yang berbelanja pagi. Beberapa pedagang yang menyasar konsumen subuh biasanya mulai menggulung alas dagangannya pada pukul 07.30 WITA. Sedangkan pedagang yang sasaran konsumennya eceran biasanya mulai menyudahi kegiatan berdagangnya pada pukul 10.00 s.d 11.00 WITA.

Beberapa pedagang mengutarakan alasan berdagang di luar pasar karena faktor keterbatasan modal. Para pedagang mengungkapkan bahwa harga sewa kios di dalam pasar cukup tinggi, ditambah kondisi perekonomian yang lemah tidak seperti masa-masa sebelumnya. "Sekarang pasarnya sepi tidak seperti dahulu. Jangankan menyewa kios, untuk modal berbelanja saja kadang tidak menutup" (Penuturan $\mathrm{Bu}$ Mastini, \pm 50 tahun, pedagang sayur di luar pasar, wawancara Agustus 2018). Beberapa pedagang juga menuturkan alasan pemilihan media atau tempat berdagang dikarenakan tempat para pedagang merupakan tempat yang tidak tetap. Para pedagang sayur yang menggunakan media mobil sebagai tempat berdagang misalnya, menjelaskan bahwa mereka tidak berdagang di Pasar Baru saja. Setelah berdagang di Pasar Baru pada pagi hari, selanjutnya mereka akan menjual sayurnya secara berkeliling ke permukiman penduduk di Kota Balikpapan. Sedangkan pedagang yang menggunakan gerobak dorong menjelaskan pemilihan media berdagangnya dimaksudkan agar lebih memudahkan memindah barang dagangannya bila terjadi penertiban atau ketika cuaca kurang mendukung.

Berbeda dengan para penjual yang berdagang di dalam pasar, pedagang di luar pasar biasanya mempunyai resiko yang lebih besar. Status mereka yang tidak terdaftar oleh pengelola pasar, dan tidak membayar retribusi pasar, kerap dianggap sebagai pedagang "ilegal". Tidak jarang selama penelitian, terjadi penertiban pedagang di sepanjang jalan masuk dari gapura masuk Pasar Baru oleh petugas. Pada beberapa kesempatan, terlihat pula pedagang di luar Pasar Baru berani menggelar alas atau tempat berdagangnya setelah petugas penertiban melakukan tugasnya. Fenomena yang seperti ini tentu menjadikan kondisi yang pelik dan membutuhkan penyelesaian penuh agar tidak terjadi konflik. Sedikit banyak para pedagang di luar pasar juga mempunyai andil dalam menjaga kelestarian pasar.

Para pedagang yang berdagang di dalam pasar, sebagian besar menggunakan lapak, kios, dan toko-toko yang menjadi tempat berdagang. Jenis pedagang yang berada di dalam pasar lebih beragam, terutama komoditas yang dijualnya. Pedagang yang berdagang di dalam pasar biasanya membuka kiosnya sedikit lebih siang dari pada para pedagang yang berada di luar pasar. Jika para pedagang di luar pasar sudah siap sebelum adzan subuh, para pedagang di dalam pasar baru bersiap buka setelah adzan subuh. Puncak keramaian yang terjadi di dalam pasar biasanya terjadi setelah subuh hingga pukul 08.00 WITA, setelah itu kondisi pasar berangsur sepi. Pedagang yang berada di dalam pasar menjual berbagai komoditas, mulai dari sayur-mayur, buahbuahan, daging-dagingan, ikan, sembako, makanan, perabot, dan berbagai kebutuhan 
rumah tangga hingga snack (makanan ringan).

Para pedagang Pasar Baru

Balikpapan yang berdagang di dalam biasanya membayar biaya retribusi pasar yang ditarik setiap hari. Retribusi atau pedagang setempat menyebutnya karcis, biasanya digunakan untuk biaya pembersihan pasar yang dilakukan oleh petugas. Para pedagang membayar biaya sewa kios, toko, atau lapak berjualan setiap tahun. Para pedagang membayarnya ke pengelola pasar. Pedagang harus memperpanjang Kartu Tanda Bukti Hak Pemakaian Bangunan (KTBHPB) setiap tahun dengan biaya sebesar Rp 250.000,00. Tidak jarang ditemui banner himbauan perpanjangan KTBHPB dan persyaratan memperpanjang kartu tersebut pada setiap sudut pasar (seperti yang terlihat pada Gambar 5). Sedangkan untuk listrik atau biaya lampu ditarik per hari sesuai dengan biaya kebersihan. Kondisi pasar yang sepi, membuat tidak sedikit pedagang yang menunggak biaya sewa dan perpanjangan KTBHPB.

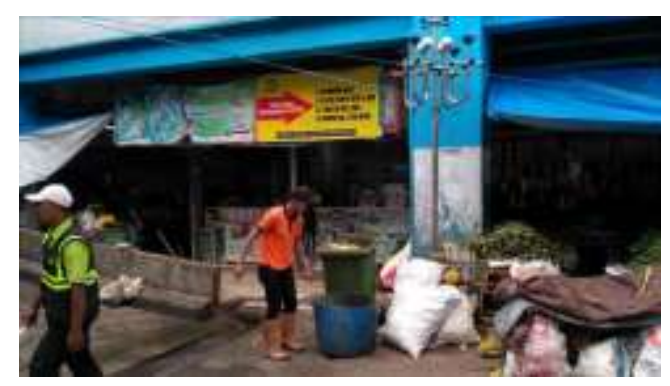

Gambar 5. Salah Satu Himbauan Persyaratan Perpanjangan KTBHPB

(Banner Warna Kuning)

Sumber: Dokumentasi Peneliti, 2018.

Pasar Baru Balikpapan, sebagai sebuah lokus sosial ekonomi menjadi pusat pertemuan masyarakat dari berbagai macam kebudayaan. Para pedagang pun mempunyai rupa yang beragam antara satu sama lain. Hal ini membuat munculnya budaya universal dan budaya parsial yang dihidupi oleh para pedagang di Pasar Baru Balikapapan.

\section{Yang Umum dan Yang Khusus: Budaya Pedagang Pasar Baru Balikpapan}

Budaya merupakan suatu sistem pola respon kebiasaan yang saling terkait dan saling bergantung antara satu dengan yang lain (Kroeber \& Kluckhohn, 1952). Budaya pasar tradisional yang dibangun oleh pemangku pasar merupakan suatu proses pemaknaan yang tiada henti. Para pedagang disadari maupun tidak, membawa nilai-nilai budaya dari mana mereka berasal dan juga menyerap budaya masyarakat lain yang teraktual pada saat kegiatan perdagangan di pasar tradisional.

Pasar sebagai lokus sosial ekonomi menjadi arena produksi nilai yang dimaknai oleh para pedagang selaku pemangku pasar. Nilai budaya sendiri dapat dipahami sebagai seperangkat kesepakatan mengenai "ukuran" suatu tindakan ataupun praktik yang dilakukan dalam kegiatan pasar tradisional. Nilai budaya ini menjadi suatu pedoman bagi para pedagang terutama dalam berperilaku di pasar tradisional. Selain sebagai pedoman, nilai budaya pasar tradisional juga menjadi penentu pola pikir para pedagang dalam berkegiatan.

Dalam konteks pedagang dan berdagang, disadari atau tidak para pedagang berusaha mencari, menyerap, dan menampilkan nilai-nilai yang dianggap universal. Misalnya saja dalam praktik menimbang, para pedagang menyepakati bahwa komoditas seperti sayur, ikan, daging, maupun komoditas lain harus dijual dengan cara ditimbang. Hal ini dimaksudkan agar menciptakan nilai percaya antara pembeli dan pedagang. Selain itu nilai-nilai keramahan juga dibangun dan disepakati sedemikian rupa oleh pedagang. Nilai-nilai yang demikian menjadi nilai yang ditampilkan oleh pedagang, nilai ini bersifat umum. Keramahan dan kejujuran menjadi nilai yang dimaksudkan agar membangun modal sosial melalui relasi dan interaksi dengan para pembeli juga pedagang lainnya. 
Selain nilai-nilai yang sengaja ditampilkan oleh para pedagang, pedagang juga mempunyai nilai-nilai khusus yang bersifat pribadi dan tidak serta-merta selalu ditampilkan di depan publik. Meskipun demikian bukan berarti nilai-nilai yang bersifat khusus ini tidak pernah nampak. Pada beberapa kesempatan nilai budaya yang bersifat khusus ini bisa menjadi perekat sosial bagi sesama komunitas. Misalnya saja, dalam keseharian sebagian besar pedagang menggunakan bahasa Indonesia sebagai bahasa sehari-hari dalam berdagang. Hal ini disebabkan bahasa Indonesia merupakan nilai universal yang mana setiap pedagang dan pembeli menggunakannya. Akan menjadi berbeda ketika pedagang yang berasal dari Jawa bertemu dengan sesama pedagang dari Jawa atau pembeli yang merupakan perantau dari Jawa. Bahasa yang digunakan bukan lagi bahasa Indonesia, tetapi lebih ke bahasa Jawa. Penggunaan bahasa Jawa ini dimaksud untuk merekatkan ikatan sosial, meskipun pada kenyataannya antara pedagang dan pembeli tidak selalu berasal dari satu daerah yang sama di Pulau Jawa. Tidak jarang, setelah mengetahui dari daerah yang sama dan mempunyai persamaan bahasa, konsumen akan berlangganan pada pedagang tersebut.

Komoditas yang diperdagangkan oleh para pedagang di Pasar Baru Balikpapan, biasanya juga menjadi penanda identitas tersendiri untuk para pedagang. Para pedagang sedikit banyak menjual komoditas perdagangan yang "dekat" dengan budaya asal para pedagang. Salah satu pedagang sayur di Pasar Baru menuturkan bahwa:

"Pedagang di sini itu berasal dari banyak daerah, kebanyakan pedagang merupakan perantau. Yang dijual juga beragam, tapi biasanya pedagang menjual barangbarang tertentu sesuai asal mereka. Seperti penjual tahu tempe di sini itu pasti orang Jawa, pedagang ikan laut yang kebanyakan orang Sulawesi
Selatan, pedagang ikan tawar yang orang Banjar, dan pedagang bumbu halus yang sebagian besar orang Minang atau Padang" (Wawancara Bu Jumi, \pm 65 tahun, bukan nama sebenarnya, Agustus 2018).

Beberapa pedagang bahkan sudah turun temurun menjual komoditas tertentu. Misalnya pedagang ikan di Pasar Baru Balikpapan yang sebagian besar merupakan masyarakat dari Sulawesi Selatan dan sudah turun temurun menjual ikan. Alasan utama para perantau dari Sulawesi Selatan ini menjual ikan karena kehidupan di tempat mereka yang juga seorang nelayan dan dekat dengan laut (Alfian, Iskandar, \& Iskandar, 2020).

Meskipun demikian hal tersebut tidak serta merta bisa menjadi generalisasi bahwa semua pedagang menjual komoditas dagangan sesuai dengan komoditas yang familiar dengan kebudayaan asalnya. Beberapa pedagang lebih memilih menjual komoditas yang dianggap potensial dengan kondisi pasar dan masyarakatnya. Misalnya saja salah satu penjual buah lai (sejenis durian) yang merupakan buah khas Kalimantan, merupakan perantau dari Madura. Pedagang tersebut menjelaskan, meskipun buah lai tidak ada di daerah asalnya tetapi buah ini menjadi salah satu buah yang banyak diminati oleh masyarakat sekitar. Melihat potensi yang tinggi untuk diperdagangkan, pedagang tersebut akhirnya menjual buah lai.

Pada sisi lain, para pedagang mempunyai pilihan logis dan terukur ketika memutuskan untuk menjual komoditas dagang tertentu. Beberapa faktor pemilihan biasanya didasarkan pada akses suatu komoditas, keminatan konsumen, persaingan dengan pedagang lain, ketersediaan modal. Tidak jarang pedagang yang merupakan perantauan menceritakan sebelum berangkat merantau dan memutuskan berdagang. Pedagang tersebut terlebih dahulu menanyakan halhal tertentu ke saudara atau perantau yang terlebih dahulu berangkat. Misalnya saja 
menanyakan kondisi pasar, pedagang apa saja yang sudah ada, bagaimana harga komoditas dagang di tempat tersebut.

Kebudayaan yang teraktual saat ini pada pedagang merupakan langkah diakronis yang terbangun dari masa lalu dan terus bergerak ke depan dengan segala perubahan dan negosiasi oleh para pemangkunya, yaitu pedagang. Misalnya saja pada masa sebelumnya banyak pedagang yang menggunakan sistem tumpuk dalam menjual ikan maupun buah, sekarang seiring perkembangan alat ukur timbangan, sebagian besar pedagang menjual buah maupun ikan menggunakan timbangan sebagai alat ukur utama. Pada masa sebelumnya pedagang hanya berdagang secara langsung (bertemu pembeli langsung), ketika penelitian ini dilakukan, tidak sedikit pedagang yang juga melayani pemesanan belanja melalui media telekomunikasi seperti Whatsapp, SMS, maupun telepon. Kebudayaan yang terbentuk di Pasar dipengaruhi oleh beberapa hal seperti: budaya asal pedagang, budaya masyarakat setempat, kondisi perekonomian pasar tradisional, peraturan pasar, maupun dinamika perkembangan teknologi. Terdapat kebiasaan atau aturan yang disepakati bersama secara formal misalnya saja peraturan pasar yang dibuat oleh pengelola pasar. Sanksi yang diterapkan jelas sehingga pedagang harus menanggung konsekuensi apabila melanggar peraturan. Pada sisi lain ada pula kebiasaan atau aturan yang dibangun secara nonformal seperti nilai keramahan dan kejujuran. Nilai ini tidak tertulis dan disepakati secara nonformal, sanksi yang diterapkan pun lebih ke sanksi sosial. Pedagang yang diketahui kurang ramah atau bahkan tidak jujur biasanya menjadi pergunjingan sendiri di kalangan pedagang. Akhirnya, kebudayaan di Pasar Baru Balikpapan pun terus dimaknai dan dinegosiasikan oleh para pedagang sesuai dengan kondisi dan kebutuhan para pedagang itu sendiri.

\section{PENUTUP}

Kebudayaan pada dasarnya merupakan suatu kesepakatan tindakan yang selalu dimaknai oleh para pemangkunya, sehingga tidak lepas dari perubahan dan transformasi. Demikian halnya dengan budaya pasar tradisional di Pasar Baru Balikpapan, yang bertransformasi dari waktu ke waktu. Transformasi budaya yang terjadi, menunjukkan bahwa para pedagang sejatinya merupakan aktor-aktor yang aktif, selalu memberikan makna, dan mempunyai pilihan-pilihan logis dalam bertindak dan memaknai budaya yang teraktual. Budaya sejatinya merupakan suatu yang abstrak dan sulit untuk didefinisikan, salah satu cara dalam melihat budaya dalam penelitian ini adalah dengan memfokuskan kajian pada tindakan atau praktik yang dilakukan oleh para pedagang di Pasar Baru Balikpapan. Akhirnya penelitian ini mencapai kesimpulan bahwa budaya pasar di Pasar Baru Balikpapan menjadi salah satu pedoman dalam bertindak bagi para pedagang pasar tradisional di Pasar Baru. Selain sebagai pedoman dalam bertindak, budaya pasar sendiri terdiri atas nilai-nilai budaya yang dengan sengaja ditampilkan oleh para pedagang. Budaya pasar di Pasar Baru Balikpapan bukan sesuatu yang alami, tetapi dikonstruksikan oleh para pemangkunya dalam waktu yang tidak sebentar dan terus mengalami perubahan.

\section{UCAPAN TERIMA KASIH}

Penulis mengucapkan terima kasih kepada SIMLITABMAS Kementerian Riset dan Teknologi atas pendanaan proyek penelitian Dr. Budiawati Supangkat MA, Surat Keputusan Nomor 10/E1/KP.PTNBH/2019 dan Nomor Perjanjian Kontrak 5097c/UN6.G /LT/2019. Kami juga mengucapkan terima kasih kepada seluruh informan yaitu para pedagang di Pasar Baru Balikpapan dan konsumen di Pasar Baru, Kota Balikpapan, atas kerjasamanya dalam penelitian ini. 


\section{DAFTAR SUMBER}

Abdullah, I. (2015). Konstruksi dan Reproduksi Kebudayaan. Yogyakarta: Pustaka Pelajar.

Alfian, R. L., Iskandar, J., \& Iskandar, B. S. (2020). Fish species , traders , and trade in traditional market: Case study in Pasar Baru , Balikpapan City , East Kalimantan , Indonesia. Biodiversitas, 21(1), 393 406.

https://doi.org/10.13057/biodiv/d210146

Belshaw, C. S. (1965). Traditional Exchange and Modern Markets. United State of America: Prentice-Hall, Inc.

Damsar \& Indrayani. (2018). Pengantar Sosiologi Pasar. Jakarta: Prenadamedia Group.

Direktorat Internalisasi Nilai dan Diplimasi Budaya. (2013). Menguak Pasar Tradisional Indonesia. Jakarta: PT. Mardi Mulyo.

Effendi, N. (1997). Pasar dan Fungsi Kebudayaan. In E. K. . Masinambo (Ed.), Koentjaraningrat dan Antropologi di Indonesia. Jakarta: Yayasan Obor Indonesia.

Effendi, N. (2016). Studi Budaya Pasar Tradisional dan Perubahan Gaya Hidup Masyarakat Pedesaan: Kasus Pasar Nagari dan Masyarakat Nagari di Provinsi Sumatera Barat 1. Jurnal Antropologi: Isu-Isu Sosial Budaya, 18 (2), 105-120.

Endres, K. W., \& Leshkowich, A. M. (Ed.). (2018). Trader in Motion: Identities and Contestations in the Vietnamese Marketplace. United State of America: Cornell University Press.

Fatterman, D. . (2010). Ethnography: Step-byStep. United State of America: Sage Publications.

Geertz, C. (1973). Thick Description: Toward an Interpretive Theory of Culture. In The Interpretation of Cultures. New York: Basic Books.

Granovetter, M. (2017). Society and Economy: Framework and Priciples. Cambridge, Massachusetts: The Belknap Press of Harvard University Press.
Gudeman, S. (2001). The Anthropology of Economy: Cummunity, Market, and Culture. United Kingdom: Blackwell Publisher.

Hefner, R. W. (Ed.). (2000). Budaya Pasar Masyarakat dan Moralitas dalam Kapitalisme Asia Baru. Jakarta: LP3ES.

Hermawan, F., Kristiani, F. \& Ismiyati. (2018). Model of Indonesian Traditional Market Revitalisation: Case Study of Five Metropolitan Cities in Java Island. Advanced Science Letter, 24, 3146-3151.

Koentjaraningrat. (1991). Metode-Metode Penelitian Masyarakat. Jakarta: PT. Gramedia Pustaka Utama.

Kroeber, A. ., \& Kluckhohn, C. (1952). Culture: A Critical Review of Concepts and Definitions. New York: Vintage Books.

Miles, M. B., \& Huberman, A. M. (1992). Analisis Data Kualitatif: Buku Sumber Tentang Metode-Metode Baru. Jakarta: UI Press.

Mulyanto, D. (2008). Orang Kalang, Cina, dan Budaya Pasar di Pedesaan Jawa. Jurnal Masyarakat dan Budaya, 10 (2), 23-40.

Polanyi, K. (1985). The Economy as Instituted Process. In M. Granovetter \& R. Swedberg (Ed.), The Sociology of Economy Life. San Francisco: Westview Press.

Powdermaker, H. (1966). Stranger and Friend: The Way of an Anthropologist. New York: W.W. Northon \& Company.

Sadilah, E., Arianti, C., Herawati, I., Moertjipto, \& Sukari. (2011). Eksistensi Pasar Tradisional: Relasi dan Jaringan Pasar Tradisional di Kota Semarang Jawa Tengah. Yogyakarta: Balai Pelestarian Sejarah dan Nilai Tradisional Yogyakarta.

Seligmann, L. (2018). Space, Place and Contentious Politics of Market Redevelopment. In Traders in Motion: Identities and Contestation in the Vietnamese Marketplace. New York: Cornel University Press.

Soulsby, A. (2004). Who is Observing Whom? Fieldwork Roles and Ambiguities in 
Organisational Case Study Research. In Fieldwork in Transforming Society: Understanding Methodology from Experience. New York: Palgrave Macmillan.

Spradley, J. P. (2007). Metode Etnografi. Yogyakarta: Tiara Wacana.

Supangkat, B. (2012). Pasar dan Perempuan Pedagang di Pasar Ujung Berung Bandung. Universitas Indonesia.

Supangkat, B., Alfian, R. L., \& Iskandar, J. (2021). Traditional Market and Women's Work In The Beringharjo Market, of Yogyakarta. Sosiohumaniora: Jurnal Ilmu-Ilmu Sosial dan humaniora, 23(1), $1-11$.

https://doi.org/10.24198/sosiohumaniora. v23i1.29807.

Valdelin, J. (2000). Produktutveckling och marknadsföring. In Qualitative Methods in Management Research. Thousand Oaks: Sage. 
Patanjala, ISSN 2085-9937 (print), ISSN: 2598-1242 (online) 